\title{
Pengembangan Kemasan Higenis dan Menarik pada Usaha Jamur Tiram Usman di Paccerakkang Kelurahan Katimbang Kecamatan Biringkanaya Makassar
}

\author{
Yusriani Mangarengi ${ }^{1 *}$, Marzelina Karim ${ }^{1}$, Santriani Hadi ${ }^{2}$, Karisman ${ }^{1}$ \\ ${ }^{1}$ Departemen Mikrobiologi, Fakultas Kedokteran, Universitas Muslim Indonesia \\ ${ }^{2}$ Parasitologi, Fakultas Kedokteran, Unversitas Muslim Indonesia
}

*Email korespondensi: yusrianiaris@yahoo.com

Telp: +6285399067512

\begin{abstract}
ABSTRAK
Di tahun 2019, terhitung sangat banyak usaha makanan-makanan baru yang mulai menjamur, baik yang bersifat musiman maupun jangka panjang. Masyarakat tentu tidak mau kehilangan kesempatan untuk memiliki bisnis makanan. Jamur berkontribusi pada serat disetiap asupan harian kita. Jamur juga memiliki banyak mineral dan vitamin yang tidak dapat diperoleh dari makanan lain. Salah satu jamur yang dapat dimakan yaitu jamur tiram. Jamur tiram mengandung asam lemak tidak jenuh, protein, vitamin B1, B2, C,dan D2, rendah kolesterol, lemak dan kalori, mengandung mineral termasuk kalsium, magnesium, zat besi, fosfor yang sangat bermanfaat bagi tubuh. Kegiatan Pelaksanaan pengabdian ini diadakan di lingkungan Usaha Jamur Tiram Usman lokasi Paccerakkang Kel. Katimbang, Kec. Biringkanaya Makassar. Dalam pengabdian masyarakat ini kami memberikan pelatihan bagi masyarakat berupa pembuatan jamur krispi yang baik tanpa bahan pengawet dan cara pembuatan kemasan yang baik, menarik dan higenis agar minat terhadap jamur tiram kepada masyarakat akan meningkat. Pengelolahan jamur dengan kemasan yang menarik dan higenis sangat penting bagi masyarakat yang untuk mencegah kontaminasi bakteri, kemasan makanan juga memperpanjang umur simpan produk, yang memungkinkan distribusi yang lebih luas dan mengurangi limbah makanan sedang menjalankan usaha mereka.
\end{abstract}

Kata kunci: Jamur Tiram; kemasan makanan; mineral; vitamin

\begin{abstract}
In 2019, enormous conversations about new foods are beginning to flourish, both of which encourage good long-term conversation. The public certainly does not want to lose the opportunity to have a food business. Mushrooms contribute to fiber in each of our daily intake. Mushrooms also have many minerals and vitamins that cannot be obtained from other foods. One edible fungus is oyster mushroom. Oyster mushrooms contain unsaturated fatty acids, protein, vitamins B1, B2, C and D2, low in cholesterol, fat and calories, contain minerals including calcium, magnesium, iron, phosphorus which are very beneficial for the body. The Community Service Activities are carried out in the Usman Oyster Mushroom Business Environment, Paccerakkang Kel. Katimbang, Kec. Makassar Biringkanaya. In this community service, we provide training for people who provide good crispy mushrooms without preservatives and how to make good, attractive and hygienic packaging so that the interest in oyster mushrooms for the community will increase. The management of mushrooms with attractive and hygienic packaging is very important for the community to prevent bacterial contamination, food packaging also extends the shelf life of products, which allows wider distribution and reduces food waste when running their businesses.
\end{abstract}

Keywords: Oyster Mushroom; food packaging; mineral; vitamin 


\section{PENDAHULUAN}

Jamur tiram memiliki warna yang putih dan terkadang seperti krem yang lembut yang mempunyai cangkang lebar seperti tiram dimana dibagian tengahnya membentuk cekungan seperti kubangan. Jamur tiram mengandung nutrisi tinggi dan berbagai metabolit sekunder lainnya yang memiliki efek farmakologis, banyak zat aktif yang baik terhadap efek terapeutik, termasuk komponen fenolik, flavonoid, terpenoid, polisakarida, lektin, steroid, glikoprotein, beberapa komponen lipid, dan ergothioneine (ET), vitamin C, beta-karoten, dan selenium.(1-3) Budidaya jamur saat ini menjadi satu-satunya bioteknologi yang ekonomis untuk daur ulang limbah lignoselulosa organik yang menggabungkan makanan kaya protein dengan pengurangan polusi lingkungan. Jamur adalah produk makanan yang semakin banyak digunakan sebagai produk makanan yang berperan penting dalam kesehatan manusia, nutrisi, dan sebagai mengatasi berbagai penyakit.(4) Jamur telah digunakan sebagai obat dari zaman dahulu, sebagai makanan rendah kalori. Sifat nutrisi, dan anti makroba pada jamur tiram dapat digunakan sebagai makanan yang dikonsumsi sehari-hari.(5) Jamur tiram mampu mengaktivasi antiinflamasi dan dapat dianggap sebagai makanan yang bisa mengatasi peradangan.(6) Selain itu, juga memiliki efek perlindungan pada hati, ginjal, otak dan paru-paru. $(2,7)$

Jika ingin usaha budidaya jamur tiram investasi yang dikeluarkan cukup murah dan bisa dilakukan secara bertahap. Usaha pengolahan jamur juga sudah sangat diminati banyak orang, dapat dijadikan jus yang dicampurkan dengan buah-buahan, dibuat pepes, aneka sayuran, atau digoreng krispi dan dijadikan dadarpun nikmat. Setelah mengelolah jamur diperlukan juga kemasan yang higenis untuk mencegah kontaminasi bakteri, kemasan makanan juga memperpanjang umur simpan produk, yang memungkinkan distribusi yang lebih luas dan mengurangi limbah makanan.(8) Data penelitian lapangan terdapat korelasi antara peningkatan penjualan sayuran dan kemasan yang menarik, atau nama produk yang menarik.(9) Oleh karena itu, pada pengabdian masyarakat ini dapat membudidayakan jamur tiram dengan pengembangan kemasan yang menarik dan higenis.

\section{METODE PELAKSANAAN}

\subsection{Tujuan Kegiatan :}

Tujuan pelaksanaan pengabdian masyarakai ini adalah pengembangkan Usaha Produksi Jamur Tiram dalam hal kemasan yang higienis dan menarik agar minat terhadap Jamur Tiram kepada masyarakat akan meningkat, menambah pengetahuan dan pemahaman masyarakat mengenai manfaat jamur tiram untuk kesehatan di lingkungan usaha 
Paccerakkang Kel. Katimbang, Kec. Biringkanaya, dan dapat memberikan pengetahuan kepada masyarakat mengenai proses pengolahan jamur tiram yang sehat di lingkungan usaha Paccerakkang Kel. Katimbang, Kec. Biringkanaya, mengembangkan produksi dalam hal kemasan yang higienis dan menarik agar minat terhadap jamur tiram kepada masyarakat akan meningkat.

\subsection{Lokasi Kegiatan Pelaksanaan}

Kegiatan Pelaksanaan pengabdian ini diadakan di lingkungan Usaha Jamur Tiram Usman lokasi Paccerakkang Kel. Katimbang, Kec. Biringkanaya Makassar.

\subsection{Persiapan Kegiatan}

Sebelum kegiatan dilakukan maka semua tempat, spanduk, peralatan dan bahan dipersiapkan terlebih dahulu. Kemudian mengadakan kontrak dengan Pak Usman Sattar di lingkungan Usaha Paccerakkang Kel, Katimbang Kec, Biringkanaya.berkaitan dengan tempat dan waktu akan dilaksanakannya pelatihan pembuatan kemasan jamur krispi.

\subsection{Pelaksanaan Kegiatan}

Kegiatan pembuatan jamur krispi pada usaha Usman Sattar di lingkungan Usaha Paccerakkang Kel, Katimbang Kec, Biringkanaya dilaksanakan pada tanggal 09 Februari 2019 di ikuti oleh 9 orang peserta.

Kegiatan pelatihan dilakukan dengan penyampaian tentang Pembuatan jamur krispi yang baik tanpa bahan pengawet, Cara pembuatan kemasan yang baik dan Higenis.

\section{HASIL DAN PEMBAHASAN}

Kegiatan dimulai dengan survei tempat Pengabdian Masyarakat di kelurahan Katimbang Kec. Biringkanaya, lalu mengajukan permohonan izin kegiatan Pengabdian Masyarakat kepada Pemilik Usaha, selanjutnya administrasi ke lokasi kegiatan dan akomodasi dan persiapan alat dan bahan.

Kegiatan pelatihan dilakukan dengan penyampaian tentang penyuluhan mengenai pengertian jamur tiram, manfaat, serta pengenalan jenis-jenis jamur tiram, praktek cara membuat kemasan yang baik dan higenis yang tidak mudah merusak konsistensi dari produk kemudian diakhiri dengan evaluasi. 


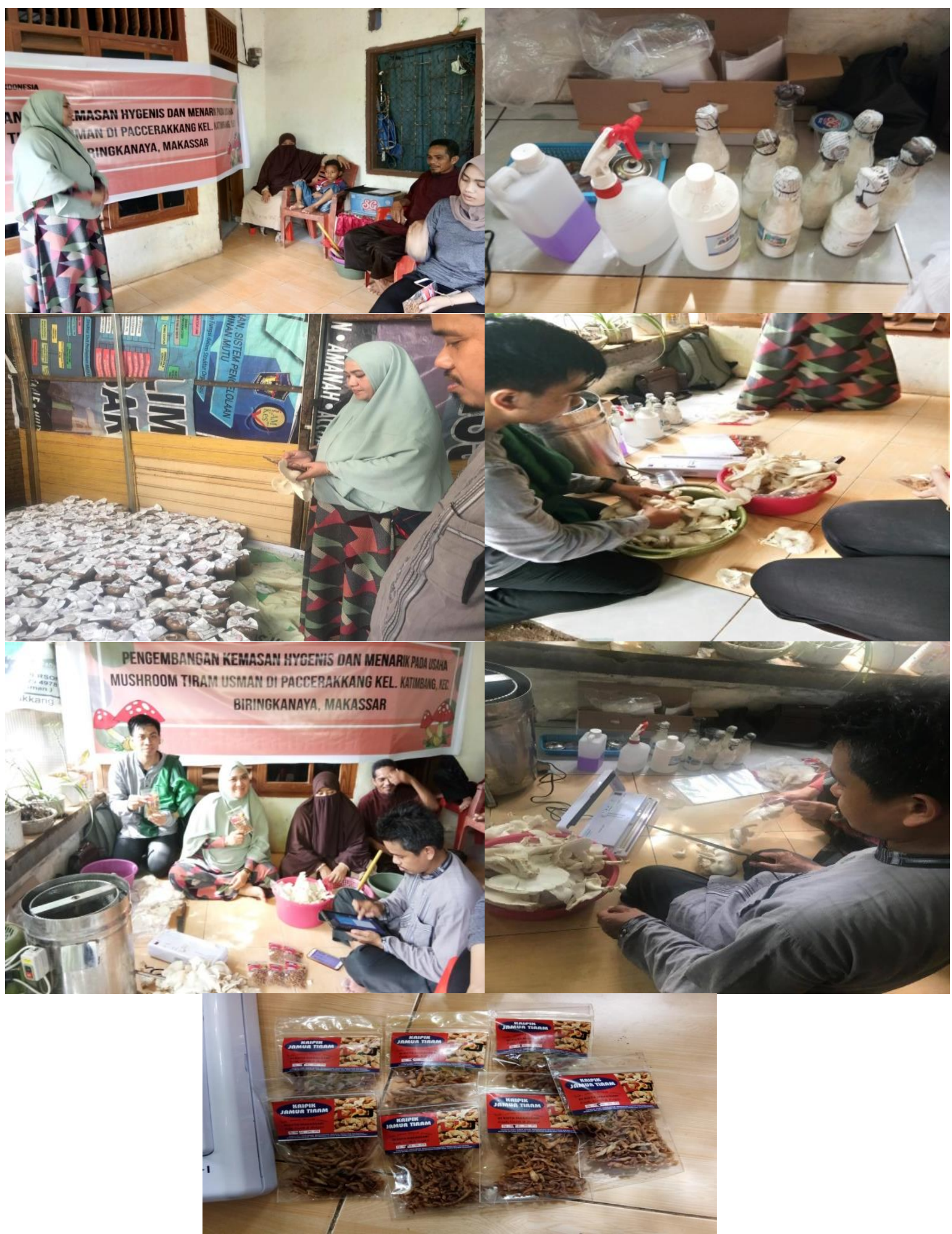

Gambar 1. Foto Kegiatan Pengembangan Kemasan Higenis dan Menarik pada Usaha Jamur Tiram

Pada kegiatan Pengabdian Masyarakat ini masyarakat diberikan pemahaman mengenai manfaat jamur tiram dan olahannya, memberikan motivasi masyarakat untuk membuat usaha mandiri yang bisa dikerjakan dari rumah dengan memanfaatkan halaman rumah. Kami berharap 
dapat memotivasi masyarakat untuk meningkatkan kreativitas dan peluang usaha mandiri.(10) Dengan adanya program Pengabdian Masyarakat ini yang berupa manajemen pengembangan usaha diharapkan dapat meningkatkan pengetahuan masyarakat tentang cara menghasilkan produk sendiri selain menghasilkan jamur. Untuk lebih jauhnya diharapkan kegiatan-kegiatan seperti ini dapat berdampak meningkatkan kesadaran masyarakat Indonesia. Universitas Muslim Indonesia, khususnya Fakultas Kedokteran dapat lebih dikenal sebagai Institusi yang peduli terhadap kemajuan ekonomi masyarakat khususnya di kota Makassar.

\section{KESIMPULAN DAN SARAN}

Kemasan suatu produk merupakan pengaruh besar bagi omset penjualan, karena itu meski produk memiliki kualitas baik tetapi tidak ditunjang dengan kemasan yang menarik maka akan menimbulkan keraguan bagi konsumen. Sebelum mendesain merk, dan membuat kemasan untuk jamur tiram krispi pak usman, kami melihat dulu profil produk jamur krispi, keaslian, nilai kejujuran produk, dan khas produk kemudian membuatkan desain untuk label produk, kami menggunakan plastic clip agar lebih modern, konsumen lebih mudah membuka, menyimpan dan menutup jamur krispi bila ingin konsumsi kembali.

Kegiatan Pengabdian Kepada Masyarakat seperti ini alangkah baiknya jika dilaksanakan secara rutin di lokasi yang berbeda, misalnya di daerah kabupaten dengan sasaran masyarakat yang benar-benar belum memahami manfaat jamur tiram.

\section{Ucapan Terima Kasih}

Terima kasih kepada pemilik usaha Jamur Tiram di Paccerakkang, Pak Dekan serta Pimpinan FK UMI serta para TIM anggota pengabdian ini sehingga pengabdian ini dapat terlaksana dengan baik dan lancar. 


\section{DAFTAR PUSTAKA}

1. Li H, Zhang Z, Li M, Li X, Sun Z. Yield, size, nutritional value, and antioxidant activity of oyster mushrooms grown on perilla stalks. Saudi J Biol Sci. 2017;24(2):347-54.

2. Rahimah SB, Djunaedi DD, Soeroto AY, Bisri T. The phytochemical screening, total phenolic contents and antioxidant activities in vitro of white oyster mushroom (Pleurotus ostreatus) preparations. Open Access Maced J Med Sci. 2019;7(15):2404-12.

3. Zhang JJ, Li Y, Zhou T, Xu DP, Zhang P, Li S, et al. Bioactivities and health benefits of mushrooms mainly from China. Molecules. 2016;21(7):1-16.

4. Tolera KD, Abera S. Nutritional quality of Oyster Mushroom (Pleurotus Ostreatus) as affected by osmotic pretreatments and drying methods. Food Sci Nutr. 2017;5(5):98996.

5. Kunjadia PD, Nagee A, Pandya PY, Mukhopadhyaya PN, Sanghvi G V., Dave GS. Medicinal and antimicrobial role of the oyster culinary-medicinal mushroom Pleurotus ostreatus (higher Basidiomycetes) cultivated on banana agrowastes in India. Int J Med Mushrooms. 2014;16(3):227-38.

6. Jedinak A, Dudhgaonkar S, Wu QL, Simon J, Sliva D. Anti-inflammatory activity of edible oyster mushroom is mediated through the inhibition of NF- $\mathrm{kB}$ and AP-1 signaling. Nutr J. 2011;10(1):52.

7. Jayakumar T, Thomas PA, Sheu JR, Geraldine P. In-vitro and in-vivo antioxidant effects of the oyster mushroom Pleurotus ostreatus. Food Res Int. 2011;44(4):851-61.

8. Claudio L. Packaging and Public Health. Env Heal Perspect. 2012;120(6):233-7.

9. Enax L, Weber B, Ahlers M, Kaiser U, Diethelm K, Holtkamp D, et al. Food packaging cues influence taste perception and increase effort provision for a recommended snack product in children. Front Psychol. 2016;6(July):1-11.

10. Shao Y, Nijstad BA, Täuber S. Linking Self-Construal to Creativity: The Role of Approach Motivation and Cognitive Flexibility. Front Psychol. 2018;9(October):1-11. 